\title{
Precision technological indices for nutrition and plant protection technology for strawberries grown in the open field
}

\author{
F.C Marin 1*, E. Chiţu1, M. Călinescu 1, M. Sumedrea 1, M. Sturzeanu 1, M. \\ Militaru ${ }^{1}$, I. Viscol ${ }^{1}$ and M. Coman'1. \\ 1Research Institute for Fruit Growing Pitesti, Romania \\ *Corresponding author email: c_marin69@yahoo.com
}

\begin{abstract}
This paper presents the efforts carried out at Research Institute for Fruit Growing between 2020-2021, in order to assess the strawberry behaviour to the hydric and biocenotic stress to improve the water and nutrients use and to build precision driven technologies that can be transferred to the farmers. Thirteen strawberry cultivars and three promising hybrids were evaluated in the field in order to evaluate the response to the fertirrigation regime, the chlorophyll fluorescence and the photosynthetic potential. We also focus on the behavior of the cultivars to the major pest and diseases, forecasts using warning modules, and an innovative mobile application and warning algorithms elaborated on the computer, and productivity potential into the first year of fructification. The ratio between the main macro-elements $N$ 12.5: $P$ 18.0: $K$ 1.0: $\mathrm{Mg} 1.5$ aiming to provid a very good nutrition to the strawberry plants and preparation for the cold season. The varietal sensitivity index to diseases (VSI\%) of the newly introduced cultivars, ranged between 0.48 at 'Dona' cultivar and 2.53 at 'Mira' cultivar but no more than 5.00 at 'Elsanta' cultivar. The average fruit weight ranged between $18.5 \mathrm{~g}$ at 'Daroyal' and 27.5 at 'Alba' cultivars. So, in this group, the productivity potential ranged between 451 to 1100 g / plant.
\end{abstract}

Keywords: strawberry, evaluation, fertirrigation, forecasting_modules, warning_algorithms.

\section{INTRODUCTION}

In Romania due to the soil and climate conditions, traditions, skills and knowledge, a wide range of horticultural products can be grown to fulfill the market's requirements and meet consumer needs. In the last decade, in our country and worldwide, it was noticed an increased demand for high-quality horticultural products obtained in economically and environmental integrated production systems, or even better under organic production system, which, if necessary, complement one another. Under the climatic changes in the latest years, many crop bottlenecks, both abiotic and biotic ones, can menace the horticultural crops in terms of diversity, stability, productivity and profitability with an impact on social and economical welfare. Plant phenology, complex flowering process, diseases management strategy and finally, the commercial value of the crop, depend on climatic conditions and need to be more and more controlled by modern techniques of cultivation. This paper presents the results obtained in a high technology system designed for the strawberry plot established in 2019 at the Fruit Growing Research Institute PitestiMaracineni, in the frame of a bilateral project Romania-Egypt, founded by ASAS Bucharest. 
Our goal is to valorize our natural conditions and to implement new monitoring, decision tools and growing techniques and to transfer them to the farmers. In this way we try to mitigate the effects of climate changes and make-farming profitable on nowadays dynamic markets. The general objective of the project is to develop and promote methodologies, devices and programming models for rapid diagnosis of key pests and diseases, and models for rapid diagnosis of the water stress in strawberry culture and ways to overcome the obstacles. Specific objectives are: optimization of fertigation in high density strawberry culture, early detection and prevention of biocenotic stress caused by pathogen and pests, elaboration of models and algorithms for warning and forecasting, transfer of the new knowledges to the farmers.

\section{MATERIALS AND METHODS}

The experimental plot consisted of 0.675 ha planted with strawberries. The biological material was represented by refrigerated plants belonging to the varieties 'Darselect', 'Daroyal', 'Dona' and 'Amandine'. Planting took place between 4-10 August 2020. Another group of plants consists of 'Queen Elisa', 'Sarom', 'Amarand' 'Real', 'Premial', 'Mira', 'Elsanta', 'Onebor' 'Alba', and a few promising hybrids were planted between 10-15 October 2020. The chosen cultivation system consisted in raised beds $62 \mathrm{~cm}$ wide, covered with plastic film and 2 irrigation tubes beneath the plastic mulch. The planting density was 55.000 plants/ha. To prevent and control weeds infestation, the intervals between the beds were sprayed with STOMP herbicide, at a rate of $2 \mathrm{l}$ commercial product per ha (more precisely $1.35 \mathrm{l} / 0.675 \mathrm{ha}$. The fertilizers were administrated to the plants by pushing them into the fertirigation pipes using a Venturi tube. In the experimental plot, it was installed a set of sensors for insolation (WD 3670i), water potential (WD6450) and leaf wetness time (WD 3666) measurement and connected to a WD1650 data logger. The climatic parameters were collected with WatchDog 2900 from Spectrum and iMetos AG from Pessl and processed both with Specware Pro.9 and iMetos 3.0 software and with MSExcel 2010. For rapid and accurate assessment of the leaves' chlorophyll content, two devices, CCM-200-Optisciences and Fluorpen FP100 were used. Thirty determinations for each variant were made as follows: three leaves from each cultivar were harvested on 30 October 2020, passed into the dark and three times in succession of the temperature's thresholds: $3.3-7.1^{\circ} \mathrm{C} ; 19.4-21.6^{\circ} \mathrm{C}$ and $36.5-43.5^{\circ} \mathrm{C}$ (increased thermal stress) (see Brestic and Zivcak., 2013). Twenty-six parameters of chlorophyll fluorescence were investigated. (Baker and Oxborough 2004; Baker and Rosenquis, 2004; Klughamer and Schreiber 2008; Papageorgiu, 2004; PerezPriego et al., 2004; Strasser et al., 2004). The plot microclimate conditions were investigated using the forecast module of Specware Pro.9 warning mod, to evaluate cultivars behavior to the diseases in the direct field observations were made on the incidence (DISINC\%) and severity (DISSEVnotes) using Deholmez scale (1995) and coupled with the mobile application BioLeaf Analysis System. Damages degrees (DD\%) and cultivar sensitivity index (VSI\%) were calculated. Two forecast algorithms built in MSExcel 2010 were elaborated for two major pests of the strawberry. All the resulted data were processed with MSExcel 2010, ANOVA and SPSS. 14.

\section{RESULTS AND DISCUSSIONS}

\section{A. Results regarding the weather data specific to the chosen location.}

Data presented in Table 1 and Figure 1 reveal that at Research Institute for Fruit Growing, the microclimate is mainly excessive continental. The year 2020 was very dry $(497.7 \mathrm{l} / \mathrm{m} 2)$ (Table 1). The driest months were April and August, with rainfall of only $21.1 \mathrm{l} / \mathrm{m} 2$ and 29.8 
$1 / \mathrm{m} 2$, the number of rainy days being $6-10$. In the air, the minimum temperature was recorded in April $\left(-3.9^{\circ} \mathrm{C}\right)$ and the maximum temperature in July $35.3^{\circ} \mathrm{C}$. It can also be observed that at the beginning of April and at the beginning of July the potential of water in the soil was between $18-48 \mathrm{kPa}$, respectively 10-18 $\mathrm{kPa}$.

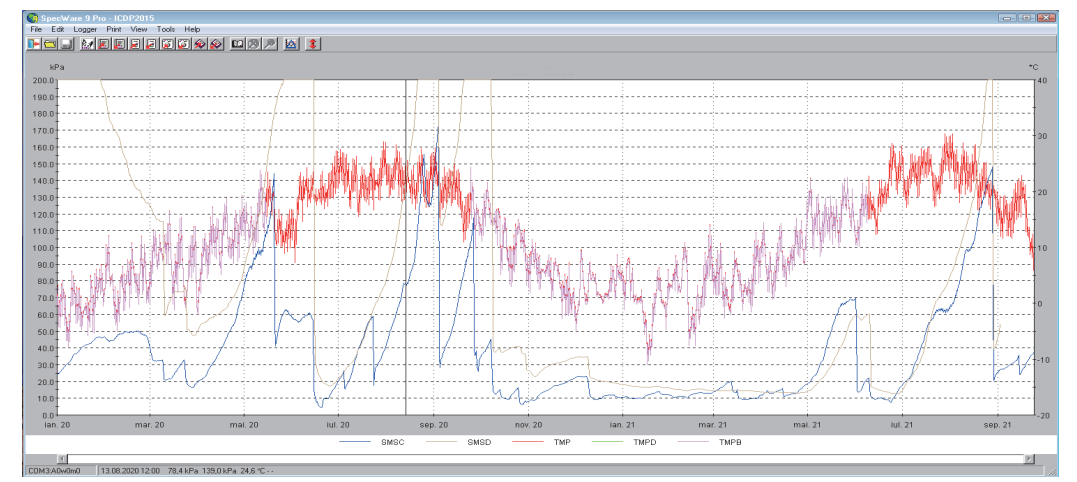

Figure 1. Soil and atmosphere conditions at Fruit Growing Research Institute, Ian. 2020 - Sep. 2021.

Table 1. Overall microclimate conditions at Fruit Growing Research Institute,

Ian.2020-Sep.2021.

\begin{tabular}{|c|c|c|c|c|c|c|c|c|c|c|c|}
\hline \multirow[b]{2}{*}{ Year } & \multirow[b]{2}{*}{ Month } & \multicolumn{5}{|c|}{ Temperature $\left[{ }^{\circ} \mathrm{C}\right]$} & \multirow{2}{*}{$\begin{array}{c}\text { Degree } \\
\text { days }\end{array}$} & \multirow{2}{*}{$\begin{array}{l}\text { Chill } \\
\text { hours }\end{array}$} & \multirow{2}{*}{$\begin{array}{c}\text { Wet } \\
\text { hours }\end{array}$} & \multirow{2}{*}{$\begin{array}{c}\text { Rain } \\
\text { Fall } \\
{[\mathrm{mm}]}\end{array}$} & \multirow{2}{*}{$\begin{array}{l}\text { Rain } \\
\text { Days }\end{array}$} \\
\hline & & High & Day & Low & Day & Mean & & & & & \\
\hline \multirow{12}{*}{2020} & Ian. & 15.0 & 25 & -10.2 & 08 & 0.2 & 2.6 & 300.3 & 12.0 & 1.8 & 4 \\
\hline & Feb. & 19.3 & 18 & -8.5 & 08 & 4.2 & 14.5 & 432.5 & 12.0 & 22.5 & 7 \\
\hline & Mar. & 23.3 & 13 & -6.1 & 17 & 7.6 & 45.5 & 448.5 & 13.0 & 30.0 & 8 \\
\hline & Apr. & 25.3 & 19 & -3.9 & 01 & 10.9 & 101.4 & 316.0 & 6.0 & 21.1 & 6 \\
\hline & Mai. & 30.1 & 11 & 4.3 & 08 & 15.0 & 169.0 & 159.0 & 21.0 & 104.1 & 14 \\
\hline & Jun. & 32.8 & 29 & 4.3 & 03 & 19.6 & 290.2 & 27.3 & 27.0 & 166.2 & 14 \\
\hline & Jul. & 35.3 & 30 & 11.6 & 15 & 22.0 & 368.9 & 0.0 & 21.0 & 52.0 & 11 \\
\hline & Aug. & 35.2 & 31 & 11.0 & 28 & 22.2 & 372.8 & 0.0 & 17.0 & 29.0 & 10 \\
\hline & Sep. & 33.8 & 01 & 6.2 & 20 & 18.9 & 372.8 & 39.8 & 19.0 & 68.2 & 0 \\
\hline & Oct. & 27.4 & 05 & -0.4 & 21 & 12.4 & 269.7 & 27.8 & 30.0 & 92.7 & 15 \\
\hline & Nov. & 17.6 & 27 & -4.9 & 28 & 4.7 & 8.0 & 37.5 & 26.0 & 8.8 & 12 \\
\hline & Dec. & 12.9 & 30 & -7.9 & 02 & 3.1 & 0.4 & 40.3 & 29.0 & 81.9 & 18 \\
\hline \multirow{9}{*}{2021} & Ian. & 13.3 & 23 & -14.1 & 17 & 0.5 & 0.8 & 438.5 & 25.0 & 73.6 & 21 \\
\hline & Feb. & 22.3 & 26 & -10.3 & 17 & 3.0 & 13.9 & 365.3 & 18.0 & 12.4 & 7 \\
\hline & Mar. & 18.8 & 28 & -6.2 & 08 & 4.1 & 16.7 & 456.8 & 17.0 & 66.8 & 15 \\
\hline & Apr. & 25.3 & 30 & -3.3 & 09 & 8.6 & 47.4 & 432.3 & 22.0 & 38.4 & 12 \\
\hline & Mai. & 28.4 & 02 & 2.5 & 09 & 15.6 & 184.0 & 102.3 & 25.0 & 65.4 & 16 \\
\hline & Jun. & 34.0 & 24 & 7.0 & 14 & 19.3 & 278.2 & 24.8 & 29.0 & 104.0 & 18 \\
\hline & Jul. & 36.0 & 28 & 12.5 & 05 & 23.5 & 408.6 & 0.0 & 18.0 & 33.5 & 9 \\
\hline & Aug. & 36.4 & 01 & 9.0 & 31 & 22.4 & 372.4 & 2.8 & 16.0 & 74.0 & 9 \\
\hline & Sep. & 30.4 & 14 & 2.7 & 24 & 15.4 & 144.6 & 118.5 & 22.0 & 12.3 & 4 \\
\hline
\end{tabular}

The vegetation season of 2021 was also very dry (Table 1). The driest months were April and July, with rainfall of only $38.4 \mathrm{l} / \mathrm{m} 2$ and $33.5 \mathrm{l} / \mathrm{m}^{2}$, the number of rainy days being 912. In the air, the minimum temperature was recorded in January $\left(-14.1^{\circ} \mathrm{C}\right)$ and the maximum temperature in July $36.8^{\circ} \mathrm{C}$. 
Table 2. Experimental plot fertilization regime applied in 2020

\begin{tabular}{|l|c|c|c|c|}
\hline $\begin{array}{c}\text { Element } \\
{[\mathrm{mg} / \text { plant] }}\end{array}$ & $\begin{array}{c}\text { Fertilization 1 } \\
21.08 .2020\end{array}$ & $\begin{array}{c}\text { Fertilization 2 } \\
31.08 .2020\end{array}$ & $\begin{array}{c}\text { Fertilization 3 } \\
09.09 .2020\end{array}$ & $\begin{array}{c}\text { Total } \\
{[\mathrm{mg} / \text { plant] }}\end{array}$ \\
\hline Nitrogen & 96 & 152 & 152 & 400 \\
\hline Phosphorus & 480 & 48 & 48 & 576 \\
\hline Potassium & - & 16 & 16 & 32 \\
\hline Magnesium & - & 24 & 24 & 48 \\
\hline Bor & - & 0.20 & 0.20 & 0.40 \\
\hline Copper & - & 0.80 & 0.80 & 1.60 \\
\hline Manganese & - & 0.32 & 0.32 & 0.64 \\
\hline Molibden & - & 0.032 & 0.032 & 0.064 \\
\hline Zinc & - & 0.20 & 0.20 & 0.40 \\
\hline
\end{tabular}

Table 3. Experimental plot fertilisation regime applied in 2021

\begin{tabular}{|l|c|l|}
\hline Comercial product & kg a. i. / ha & \multicolumn{1}{|c|}{ Phenophase } \\
\hline Kristalon 13-40-13 (yellow) & 30 & Vegetation start \\
\hline Calcinit & 100 & Vegetation start and intense growing \\
\hline Kristalon 19-6-20 (blue) & 100 & Foliage development, before and after harvest \\
\hline Kristamag & 30 & Blooming time \\
\hline Kristalon 12-12-36 (red) & 60 & Blooming time \\
\hline Kristalon 6-12-36 (orange) & 85 & Fruits increase and fruits beginning of ripening \\
\hline *Note: The fertilizers used contains various arrays of microelements. \\
\hline
\end{tabular}

\section{B. Results regarding the dynamics of chlorophyll fluorescence and the photosynthetic potential of the studied strawberry cultivars.}

Table 4. Correlation between air temperature and OJIP indicators of leaf chlorophyll fluorescence

\begin{tabular}{|c|c|c|c|}
\hline $\begin{array}{c}\text { Indicator of chlorophyll } \\
\text { fluorescence }\end{array}$ & $\begin{array}{l}\text { Simple correlation } \\
\text { coeficient Pearson }\end{array}$ & $\begin{array}{l}\text { Significance } \\
\text { (2 tailed) }\end{array}$ & $\begin{array}{c}\text { Statistic significance } \\
\text { symbol }\end{array}$ \\
\hline (l) & -0.702 & 0.000 & 000 \\
\hline Fv/Fm & -0.684 & 0.000 & 000 \\
\hline Phi_Po & -0.684 & 0.000 & 000 \\
\hline Fm/Fo & -0.631 & 0.000 & 000 \\
\hline Fv/Fo & -0.631 & 0.000 & 000 \\
\hline Pi/Abs & -0.490 & 0.000 & 000 \\
\hline Fv & -0476 & 0.000 & 000 \\
\hline Area & -0442 & 0.000 & 000 \\
\hline Fm & -0.398 & 0.000 & 000 \\
\hline $\mathbf{F i}$ & -0.356 & 0.000 & 000 \\
\hline Fix Area & -0.320 & 0.000 & 000 \\
\hline Vi & -0.279 & 0.000 & 000 \\
\hline Phi_Eo & -0254 & 0.001 & 00 \\
\hline Fj & -0.238 & 0.003 & oo \\
\hline Vj & -0.191 & 0.017 & 0 \\
\hline Sm & -0.151 & 0.060 & \\
\hline Psi_o & 0.183 & 0.022 & $*$ \\
\hline $\mathbf{N}$ & 0.253 & 0.001 & $* *$ \\
\hline Fo & 0.349 & 0.000 & $* * * *$ \\
\hline Phi_Pay & 0.352 & 0.000 & ***** \\
\hline Mo & 0.429 & 0.000 & $* * *$ \\
\hline Phi_Do & 0.484 & 0.000 & ***** \\
\hline ETo/RC & 0.695 & 0.000 & $* * * *$ \\
\hline TRo/RC & 0.716 & 0.000 & $* * * *$ \\
\hline DIo/RC & 0.719 & 0.000 & $* * * *$ \\
\hline ABS/RC & 0.729 & 0.000 & *:*** \\
\hline
\end{tabular}

The investigations carried out in 2020 and 2021 aimed to check the studied cultivar's behaviour under the continental excessive climate and the efficiency of the fertirigation measures applied specially to overcome the hydric and nutritional stress. This was done especially by analyses of chlorophyll fluorescence dynamics and the photosynthetic potential, taking into account 26 OJIP parameters. Very high temperatures $\left(>35^{\circ} \mathrm{C}\right)$ had a 
depressive effect on Ss - the smallest inflection of the transient curve of photosynthesis and on Fv/Fm - the quantum potential of photosystem II (0.69-0.72, compared to 0.8 - optimal) and to stimulate energy dissipation (see OJIP ETo/RC, TRo/RC, DIo/RC and ABS/RC indicators) (Table 4). The chlorophyll content index is positively correlated very significantly with the indicators of chlorophyll fluorescence - OJIP, of quantum production or efficiency, Psi_o, Phi_Eo and Pi_Abs, but also with Fv/Fm the quantum potential of IInd photosystem (Table 5).

Table 5. Correlation between leaf chlorophyll index and OJIP fluorescence indicators

\begin{tabular}{|c|c|c|c|}
\hline $\begin{array}{l}\text { Indicacator of chlorophyll } \\
\text { floorescence }\end{array}$ & $\begin{array}{l}\text { Simple correlation } \\
\text { coeficient Pearson }\end{array}$ & $\begin{array}{l}\text { Significance } \\
\text { (2 tailed) }\end{array}$ & $\begin{array}{c}\text { Statistic significance } \\
\text { symbol }\end{array}$ \\
\hline Mo & -0.483 & 0.000 & 000 \\
\hline $\mathrm{Vj}$ & -0.463 & 0.000 & 000 \\
\hline Fo & -0.279 & 0.000 & 000 \\
\hline Phi_Do & -0.275 & 0.001 & 000 \\
\hline $\mathbf{F j}$ & -0.257 & 0.001 & 000 \\
\hline DIo/RC & -0.206 & 0.010 & oo \\
\hline ABS/RC & -0.183 & 0.022 & 0 \\
\hline Vi & -0.182 & 0.023 & \\
\hline TRo/RC & -0.163 & 0.042 & \\
\hline $\mathrm{N}$ & -0.036 & 0.659 & \\
\hline $\mathbf{F i}$ & -0.029 & 0.717 & \\
\hline Phi_Pav & 0.000 & 1.000 & \\
\hline ETo $/$ RC & 0.006 & 0.937 & \\
\hline Sm & 0.043 & 0.591 & \\
\hline Fix Area & 0.084 & 0.297 & \\
\hline Fm & 0.100 & 0.213 & \\
\hline Area & 0.109 & 0.175 & \\
\hline Fv & 0.153 & 0.056 & \\
\hline Ss & 0.201 & 0.012 & $*$ \\
\hline Fv/Fm & 0.264 & 0.001 & $* *$ \\
\hline Phi_Po & 0.264 & 0.001 & $* * *$ \\
\hline Fv $/$ Fo & 0.336 & 0.000 & $* * *$ \\
\hline Fm/Fo & 0.336 & 0.000 & $* * *$ \\
\hline Psi_o & 0.472 & 0.000 & $* * *$ \\
\hline Phi_Eo & 0.544 & 0.000 & $* * *$ \\
\hline Phi_Abs & 0.555 & 0.000 & $* * *$ \\
\hline
\end{tabular}

B. Analysis of the risk of attack using software modules of WatchDog automatic station and the level of pathogens damages using field evaluation and mobile phone application BioLeaf Foliar Analysis.

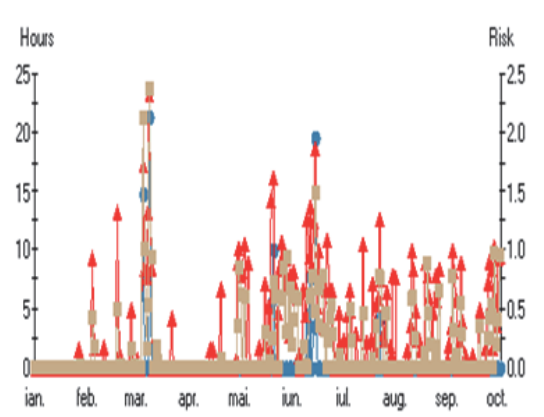

Figure 2. Attack risk of the grey mold

- Botrytis cinerea on strawberry in 2020

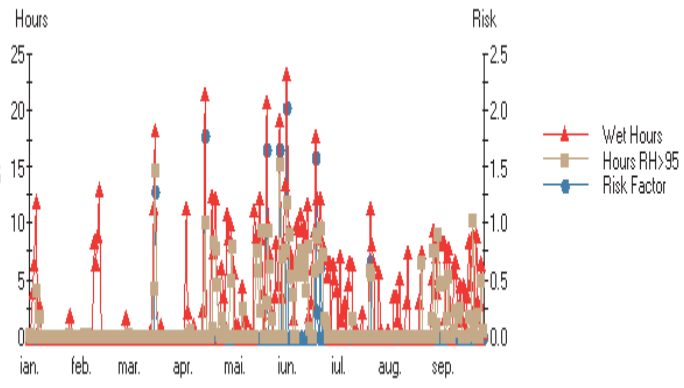

Figure 3. Attack risk of the grey mold

Botrytis cinerea on strawberry in 2021.

Assessment of figures 2 and 3 reveal that both in 2020 and 2021 the risk of grey mold attack was high in May and June (note 2.0-2.5), when due to the precipitation amount (104-106.2 $\mathrm{l} / \mathrm{m} 2$ ) and the leaf wetness period ranging between 17-23 h daily, good conditions were created for the fungal infection. 
Data of figures 4-6 reveals the strawberry cultivar's behavior to fungal diseases attack. As regard the strike of red spot Diplocarpon earliana, the most sensitive cultivars were 'Amarant', 'Darselect', 'Elsanta' and 'Mira' (DD\%=2.50), while to the white spot Mycosphaerella fragarie, 'Amandine' cultivar was the most sensitive (DD $\%=0.70)$.

From Figure 7 it can be observed that the sensitivity index to diseases (VSI\%) of the newly introduced cultivars, ranged between 0.48 at 'Dona' cultivar and 2.53 at 'Mira' cultivar but no more than 5.00 at the standard 'Elsanta' cultivar.

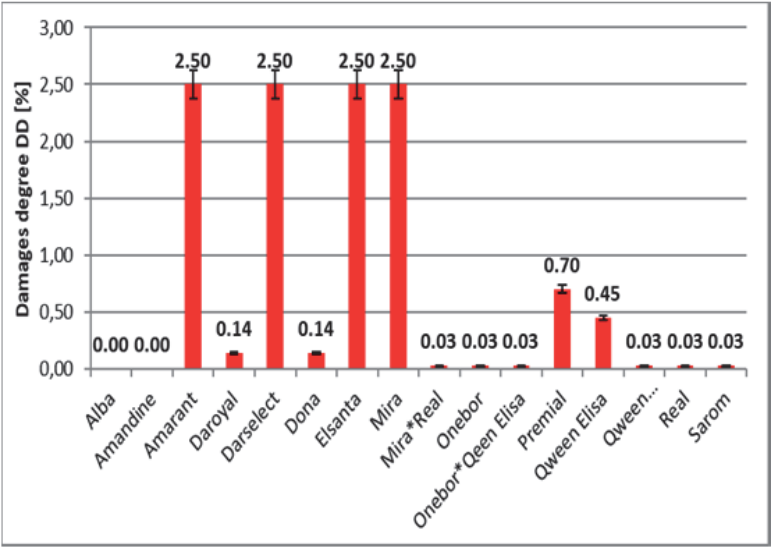

Figure 4. Damages degree DD\% caused by Diplocarpon earliana on strawberries in the experimental plot, June-July 2021

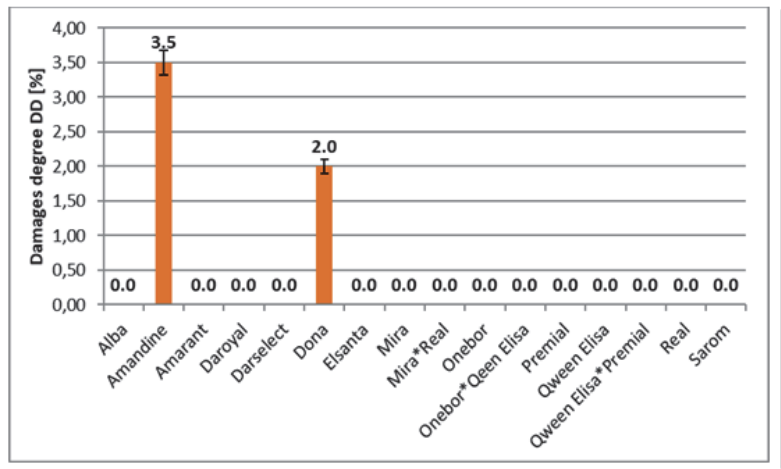

Figure 6. Damages degree DD\% of Colletotrichum acutatum on strawberries in the experimental plot, June-July, 2021

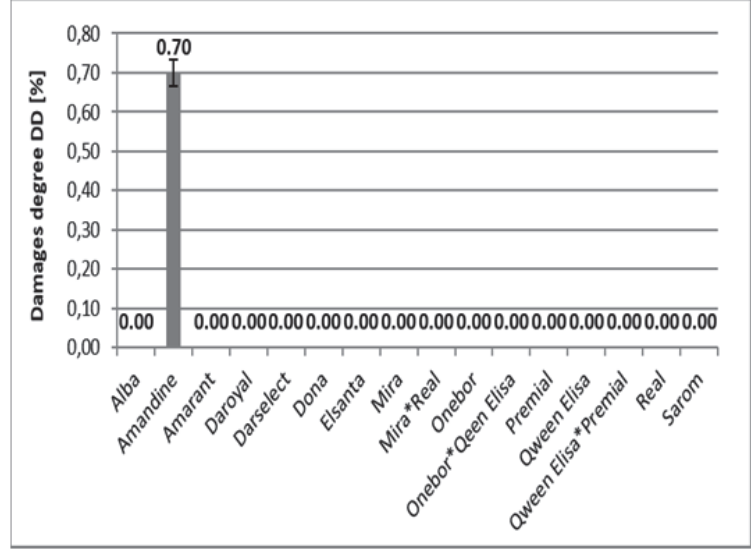

Figure 5. Damages degree DD\% caused by Mycosphaerella fragarie on strawberries in the experimental plot, June-July 2021

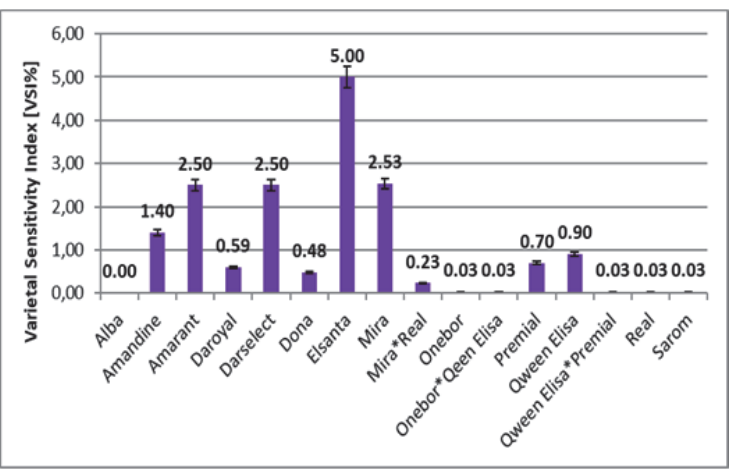

Figure 7. Cultivar sensitivity Index [VSI\%] on strawberries in the experimental plot, 2021

\section{Results in pests forecast modeling}

For to important pests of strawberry fields, bilberry tortrix - Aphelia viburna and strawberry weevils - Othiorhyncus spp., two forecast models were elaborated using MSExcel 2010 facilities (Table 6 and 7). By introducing into models, the daily temperatures over the thermal threshold of $9.0^{\circ} \mathrm{C}$, respectively $4.5^{\circ} \mathrm{C}$ can be obtained the degrees sums necessary for the pests to reach a certain development stage of the life cycle.

These are simple forecasting models, that can be used bay every strawberry grower, used on a PC or tablet, to better chose and apply the insecticide treatments in strawberry fields. 
Table 6. Forecast model for the biological cycle of strawberry weevils- Othiorhyncus spp.

\begin{tabular}{|c|c|c|c|c|l|}
\hline Date & $\begin{array}{c}\text { Sum of degrees over } \\
\text { termic treshold T*C } \mathbf{*} \\
\mathbf{4 , 5}\end{array}$ & $\begin{array}{c}\text { Sum of degrees } \\
\text { achieved over the } \\
\text { termic treshold } \\
\mathbf{T}^{*} \mathbf{C}=\mathbf{4 , 5}\end{array}$ & Life Cycle / Stage & Alert & \multicolumn{1}{|c|}{ Alert message } \\
\hline May 9 & 295.6 & 365.3 & nimph & A1 & $\begin{array}{l}\text { A1. The conditions are met for the nymph } \\
\text { development }\end{array}$ \\
\hline May 29 & 568.9 & 653.30 & adult & A2 & $\begin{array}{l}\text { A2. The conditions are met for adults occurrence, } \\
\text { apply insecticides based on: acetamiprid, tau- } \\
\text { fluvalinate or lambda-cyhalotrin, etc. }\end{array}$ \\
\hline June 17 & 814.5 & 946.21 & egg & A3 & $\begin{array}{l}\text { The conditions are met for adults meeting and } \\
\text { eggs laying; apply ovicide type insecticide. }\end{array}$ \\
\hline July 3 & 1087.3 & 1237.71 & adults on retreat & A4 & $\begin{array}{l}\text { The conditions are met for the adult's attack on } \\
\text { weeds and wilde plants, apply insecticides based } \\
\text { on acetamiprid or tau-fluvalinate or lambda- } \\
\text { cihalotrin, etc. }\end{array}$ \\
\hline
\end{tabular}

Table 7. Forecast model for the biological cycle of bilberry tortrix - Aphelia viburna

\begin{tabular}{|c|c|c|c|c|c|}
\hline Month & $\begin{array}{c}\text { Temperature } \\
\text { degrees sum over } \\
\text { the te rmal } \\
\text { treshold } \\
\mathbf{T}^{*} \mathbf{C}=\mathbf{9 , 0}\end{array}$ & $\begin{array}{c}\text { Achieved } \\
\text { te mperature degrees } \\
\text { sum over the termal } \\
\text { treshold } \\
\mathbf{T}^{*} \mathbf{C}=\mathbf{9 , 0}\end{array}$ & Life cycle/Phase & Alert & \multicolumn{1}{|c|}{ Alert mes sage } \\
\hline April & 24.4 & 78.60 & G1 pre-ovipozitary period & A1 & Start the culture monitoring. \\
\hline May 19 & 120 & 213.2 & G1 embrions development & A2 & $\begin{array}{l}\text { G1 embryons occurrence. Continue the } \\
\text { culture monitoring. }\end{array}$ \\
\hline June 10 & 336 & 475.4 & G1 larva dvelopment & A3 & $\begin{array}{l}\text { G1 larvas occurred. Apply T2 with } \\
\text { homologated insecticide larvicide, based on ... }\end{array}$ \\
\hline June 19 & 431.5 & 588.30 & Nimph occurrence & A4 & $\begin{array}{l}\text { G1 larva occured. Apply T3 with homologated } \\
\text { insecticide larvicide omologate, based on ... }\end{array}$ \\
\hline June 30 & 576 & 737.22 & G2 adults occurrence & A5 & $\begin{array}{l}\text { G2 adults occurred. Apply T4 with } \\
\text { homologated insecticide adulticide, based on.. }\end{array}$ \\
\hline July 1 & 600.4 & 746.42 & G2 pre-ovipozitary period & A6 & $\begin{array}{l}\text { G2 adults occurred. Apply T5 with } \\
\text { homologated insecticide adulticide, based on .. }\end{array}$ \\
\hline July 10 & 720.4 & 815.02 & G2 larva occurrence & A7 & $\begin{array}{l}\text { G2larva occurred. Apply T6 with homologated } \\
\text { insecticide larvicide based on... }\end{array}$ \\
\hline
\end{tabular}

\section{Results regarding the strawberry cultivars productivity potential.}

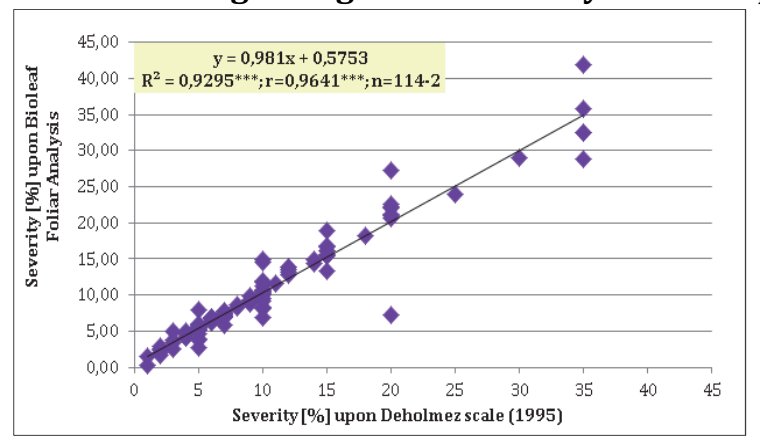

Figure 8. Correlation between attack severity estimated upon Deholmez scale, (1995) and with mobile application Bioleaf Foliar Analysis

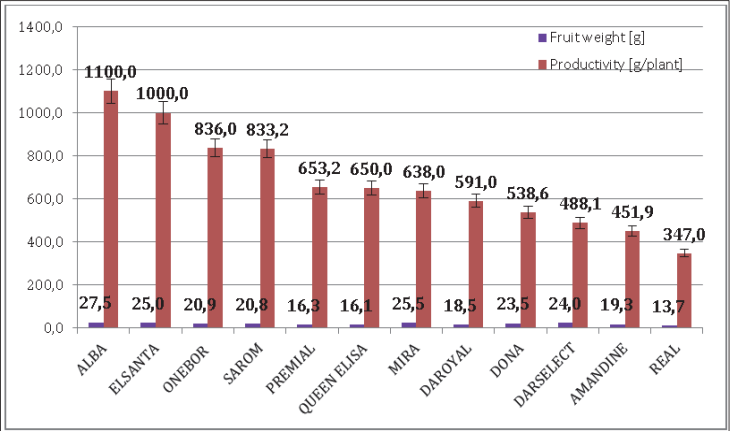

Figure 9. Results regarding the strawberry cultivars productivity potential in the first year of exploitation (2021)

Using the severity assessment scale Deholmez (1995), and the mobile application BioLeaf Foliar Analysis, a correlation was established which is described by the equation $\mathrm{Y}=0.981 \mathrm{x}+0.5753$, with the regression coefficients $\mathrm{R}^{2}=0.9295^{* * *}$ and $\mathrm{r}=0.9641^{* * *}$, which are statistical insured at 112 pairs of values. (Figure 8).

Assessment of Figure 9, reveals that regardless of their origins the studied strawberry cultivars exhibit a high productivity potential. This fact means that especially the cultivars from the Southern climate 'Alba', 'Daroyal', 'Darselect', 'Dona', 'Amandine', 'Onebor', and 'Mira', overcome the hydric and biotic stress, registered during the vegetation periods 20202021. In this sense, the average fruit weight ranged between $18.5 \mathrm{~g}$ at 'Daroyal' and 27.5 at 
'Alba' cultivar. So, at these cultivars' groups, the productivity potential ranged between 451$1100 \mathrm{~g} /$ plant.

\section{CONCLUSIONS}

During the summer, the most affected by the high temperatures was the 'Amandine' cultivar, followed by 'Daroyal' and 'Darselect', in the intermediate position, and the least affected was the 'Donna' cultivar, the differences between the three classes of cultivars being significant insured. The mobile application BioLeaf Foliar Analysis can be used for rapid assessments of diseases intensity in strawberry fields, is simple and reliable and can be recommended to strawberry growers.

The forecasting models for bilberry tortrix - Aphelia viburna and strawberry weevils Othiorhyncus spp., can be used by every strawberry grower, runed on a PC or tablet, to better choose and apply the insecticide treatments in strawberry fields. Regardless of their origins, the studied strawberry cultivars exhibit a high productivity potential. This fact means that especially the cultivars from the Southern climate 'Alba', 'Daroyal', 'Darselect', 'Dona', 'Amandine', 'Onebor', and 'Mira', overcome the hydric and biotic stress registered during the vegetation periods 2020-2021.

\section{ACKNOWLEDGEMENTS}

The study is part of the 2019-2021 bilateral research project "Precision agriculture technology for horticultural crop protection as service for climate resilient farming" which in Romania is supported by The Academy of Agriculture and Forestry Sciences, 'Gheorghe Ionescu Sisesti', from Bucharest.

\section{REFERENCES}

1. Baker N. R. and K. Oxborough, (2004). Chlorophyll fluorescence as a probe of photosynthetic productivity. From Chapter 3, "Chlorophyll a Fluorescence a Signature of Photosynthesis", edited by Georg Papaqeorgiou and Govindjee, published by Springer 2004, PO Box 17, 3300 AA Dordrecht, The Netherlands, pages 66-79;

2. Baker N.R, Rosenquist E. (2004). Applications of chlorophyll fluorescence can improve crop production strategies: an examination of future possibilities, Journal of Experimental Botany, 55(403):1607-1621;

3. Brestic M. and Zivcak M., (2013). Molecular Stress Physiology of Plants. Dordrecht: Springer; 2013. PSII fluorescence techniques for measurement of drought and high temperature stress signal in crop plants: protocols and applications. 87-131;

4. Deholmez Natalie, Odile Carisse, Laureau M. and Shahrokh Kaniyadeh, (1995). Susceptibility of Strawberry Cultivars and Advanced Selections to Leaf Spot Caused by Mycosphaerella fragariae, HortScience, Vol 30(3): 595-595, June 1995.

5. Klughammer C. and U. Schreiber, (2008). Complementary PS II quantum yields were calculated from simple fluorescence parameters measured by PAM fluorometry and the Saturation Pulse method. PAM Application Notes 1, Heinz Walz GmbH, Effeltrich, Germany: 27 -35;

6. Papageorgiou George C., (2004). Chlorophyll and fluorescence are a signature of photosynthesis. Advances in photosynthesis and respiration, 19. Dordrecht, The Netherlands [u.a.] Springer 2004. ISBN: 140203217X 9781402032172, XXIV, 7, 818 S;

7. Perez-Priego, O. Zarco-Tejada, P.J. Miller, J.R. Sepulcre-Canto, and G. Fereres, E., (2005). Detection of water stress in orchard trees with a high-resolution spectrometer through chlorophyll fluorescence in-filling of the 02-A band. Geoscience and Remote Sensing, Volume: 43, Issue: 12, ISSN: 0196-2892, page(s): 2860- 2869;

8. Strasser R.J, Tsimilli-Michael M., and Srivastava A. (2004) - Analysis of Chlorophyll a Fluorescence Transient. From Chapter 12, "Chlorophyll a Fluorescence a Signature of Photosynthesis", edited by George Papaqeorgiou and Govindjee, published by Springer 2004, PO Box 17, 3300 AA Dordrecht, The Netherlands, page 340;

***Manual of Opti-Sciences (http://www.optisci.com/cf.htm - Stress Testing);

***SpecWare 9 User Guide (Pro \& Basic) - Product manual, SpecWare Software (C) 1997-2012 Spectrum Technologies, Inc., IL, USA, 52 pp. 